\title{
The Implementation of Inclusive Learning In Muhammadiyah Elementary School of Dadapan, Yogyakarta \\ Dadapan, Yogyakarta
}

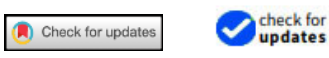

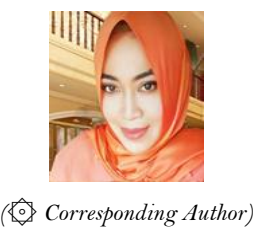

\author{
${ }^{3,4}$ Department of Education Management, Universitas Ahmad Dahlan, Indonesia. \\ Email: utma1807046015@webmail.uad.ac.id Tel: +628190427088s \\ Email: suyatno@pgsd.uad.ac.id Tel: +6285292453242 \\ ¿Email: achadisantosa@mp.uad.ac.id Tel: +6285292466101 \\ ${ }^{2}$ Department of Islamic Education, Universitas Ahmad Dahlan, Indonesia. \\ EEmail:hendro.rvidodo@pgsd.uad.ac.id.Tel:+628121573480
}

\section{ABSTRACT}

This research aims to illustrate an inclusive learning plan, implementation, and evaluation in Muhammadiyah elementary school of Dadapan, Turi, Yogyakarta. This research used a qualitative research type with a cases study approach. The data collection technique used in-depth interviews, observing the participants, and documentation. The data analysis technique used was data collection, data reduction, data presentation, and conclusion withdrawal. The research results show that: 1) inclusive learning plan was conducted by making learning devices based on curriculum 2013. Syllabus and learning implementation plan enforced generally, for children with special needs used the indicators according to their abilities. 2) The learning implementation used varied methods. The method frequently used was a lecture, discussion, question, and answer methods. The teachers used the methods according to the subject material and the student's ability. Learning media used in the learning was media based-technology such as LCD and laptop. Learning media is a simple concrete tool used to serve the children with special needs who require assistance except using methods by the laptop. 3) The learning evaluation was based on curriculum 2013 by using four criteria of assessment, such as the assessment of social, spiritual, knowledge, and skills. The evaluation was conducted through two types of tests, including oral test and written test. The evaluation used an even and odd semester test conducted in the middle and the end of years. The findings of this study recommend the importance of planning, implementing, and evaluating inclusive learning for children with special needs in primary schools.

Keywords: Inclusive learning, Learning plan, Learning implementation, Learning evaluation.

DOI: $10.20448 / 804.5 .1 .123 .133$

Citation | Utma Masniyati Saniya; Hendro Widodo; Suyatno; Achadi Budi Santosa (2020). The Implementation of Inclusive Learning In Muhammadiyah Elementary School of Dadapan, Yogyakarta. American Journal of Education and Learning, 5(1): 123-133.

Copyright: This work is licensed under a Creative Commons Attribution 3.0 License

Funding: This study received no specific financial support.

Competing Interests: The authors declare that they have no competing interests.

History: Received: 5 June 2020/ Revised: 9 July 2020/ Accepted: 3 August 2020/ Published: 27 August 2020

Publisher: Online Science Publishing 


\section{Highlights of this paper}

- This case study research aims to illustrate the implementation of inclusion learning in Muhammadiyah Elementary School of Dadapan, Turi, Yogyakarta, Indonesia.

- The findings of this study recommend the importance of planning, implementing, and evaluating inclusive learning for children with special needs in primary schools.

\section{INTRODUCTION}

Since the inclusive education published, the reception and appreciation from society are very high, so that the implementation is rapidly growing and developing (Tarnoto, 2016). Inclusive education always brings innovation to give a better service for the students, especially students with special needs. In real life, children with special needs exist not only in the general school but also in the schools for disabilities. Many special-needs children are in regular school, especially those who learn in elementary school (Murtie, 2016). The tendency of parents of specialneeds children to put their children in the regular school is very high, and this encourages the schools to improve their quality of educational services especially for the learning process in the class, the teachers are not required to distinguish student's physical and psychological condition (Stainback, 1990).

The implementation of education in Indonesia is still relatively not maximized, especially for the management of inclusive education in elementary schools. Based on the research conducted by Mangope, Mannathoko, and Kuyini (2013) showed that there is still a lack of the teacher's understanding to modify the instruction in the class, especially to fulfill the special-needs child necessities. While the abovementioned research is enforced by to find out the problems related to the children with special needs leads to the teachers who struggle to use the variety of the learning methods, so that it causes ineffective learning. Besides, Indiyanto (2013a) stated that the inclusive education is an educational service system that gives the opportunities for all of the students to learn in the regular school by holding on the diversity and individual needs.

Based on reality, it needs improvement to be able to implement inclusive educational learning management. Schools as organizers should be able to give learning managerial service of inclusive education for special-needs children With a decent and qualified learning system according to student's conditions, potential, and individual needs to form a social human being integral to family, society, and state.

To support the implementation of inclusive education grown in regular schools, the involvement of school management is essential. This involvement includes school program arrangement for inclusive educational implementation, friendly openness culture establishment for all of the people, facility and infrastructure equipment, perception establishment among teachers and staff involved at school, also network building with other supporting parties. Without any good school management support, the process of learning management will experience many obstacles (Dwiyanto, 2017). Unfortunately, until this time, the guideline of the learning management model in inclusive educational implementation, especially in Turi sub-regency, still does not exist. Therefore, the research on the implementation of inclusive learning in the Muhammadiyah Elementary School Dadapan is very important to conduct.

There are many kinds of research on the learning management strategy. One of them is Amka (2017) who had been reviewed the inclusive character education for special-needs children in regular school. Of the research, it can be concluded that the implementation of the inclusive character education signed by child-friendly learning, empathy, student-centered learning, and the learning based on student's needs. The abovementioned research is in line with the research by Ari (2005) that examines the learning implementation in Batu city, Malang. The finding resulted that inclusive learning had many constraints due to the student's conditions that were irregularly changed. Furthermore, it needed cooperation among parties to overcome the obstacles. Similarly, the results of the research 
conducted by Kim (2014) is that discussed specifically about the education followed by relevant policy introduction of specific and inclusive education.

The study of the most recent three kinds of research showed that the learning management strategy of inclusive education encountered obstacles and did not run properly. The strategy of learning implementation described inclusive educational learning plan, learning implementation, and learning evaluation were not conducted yet. Inclusive education program for students with special needs has been regulated in the Regulation of Ministry of Education Number 70 of 2009 (Menteri Pendidikan Nasional, 2009) that inclusive education conducts to acquire equal rights. Therefore, the strategy of inclusive educational learning management needs to research.

Based on the observation results and preliminary, it was found that Muhamamdiyah elementary school of Dadapan, Turi, was the only one located in Turi sub-regency that organized inclusive education. Currently, Muhamamdiyah elementary school of Dadapan has eighteen children with special needs in the category of a slow learner and Tuna Dhaksa (mobility abnormalities). The school has special guidance teachers who attend to the school two days a week to service children with disabilities. As executor of inclusive education, Muhammadiyah elementary school of Dadapan represents the achievement and good quality of learning. It was proven by much achievement in the various competition followed by regular students and special-needs students.

Learning implementation conducted in Muhamamdiyah elementary school of Dadapan, Turi, still has many problems to solve, either from the students or the special guidance teachers. The problems appeared when the school started to plan, implement, and evaluate inclusive educational learnings.

Based on the information from classroom teacher, learning management strategy in inclusive education implementation in Muhamamdiyah elementary school of Dadapan, Turi, an be a reference for principals, class teachers, special guidance teachers, and stakeholders who organize inclusive education in regular school to implement learning management for special-needs children. This research is expected to enrich the treasure of science and the contribution of alternative theory about inclusive educational learning management for children with disabilities optimally according to the development and special-needs child necessities. The questions of this study are:

1. How is the inclusive learning plan in Muhammadiyah elementary school of Dadapan?

2. How is the inclusive learning implementation in Muhammadiyah elementary school of Dadapan?

3. How is the inclusive learning evaluation in Muhammadiyah elementary school of Dadapan?

\section{LITERATURE REVIEW}

\subsection{Inclusive Education in Indonesia}

Hildengun Olsen, quoted by Tarmansyah (2007) described that inclusive education is a school accommodated by all of the children without seeing the condition of physic, intellectual, socio-economic, linguistic, and others. According to Smith (2006) inclusive education is the education involving all of the students, without exception, in regular education. Meanwhile, Sukinah (2010) stated that inclusive education is the multicultural Insight educational implementation helping the students to understand, receive, also respect other people of different ethnicities, culture, value, personality as well as physical and psychological functions. As Indiyanto (2013b) said, inclusive education is an educational service system of all children in regular school by respecting diversities and individual needs. In line with Kustawan (2012) inclusive education purposes give an immense opportunity for the students, as well as respect the diversities also not commit a discriminatory to all of the children.

According to all of the abovementioned statements, inclusive education is different from education generally. It is caused that inclusive education focuses on child and environmental interactions that become part of educational 
service based on a variety of child needs. In the inclusion school, all of the students service optimally without discriminating one to another. Inclusive education creates a tolerance as well as respect others regardless of their physic, intellectual, socio-economic, and linguistic altogether to acquire educational service in a regular school in all of the educational units.

\subsection{The Implementation of Inclusive Education in the Schools}

Stated that the implementation of inclusive education needs preparation related to complex problems. Prastiyono (2013) also revealed that inclusive education implementation considers many factors. According to Staub and Peck (Illahi, 2013) uttered that inclusive education put the children with disabilities with mild, moderated, and severe level fully in a regular class.

The learning is that the system consisted of an introduction, core, and closing. According to Hamalik (2008) instruction is as a compiled combination consisting of human, material, facilities, equipment, procedures that influence each other to achieve learning objectives. Meanwhile, according to Nana (1989) learning is a systematic and deliberate efforts to create interactive and educative activities between two parties, students, and teachers conducting learning activities. Law Number 20 of 2003 stated that learning is the interaction process of students with teachers, and learning resourcees in a learning environment.

\section{METHOD}

\subsection{The Type of Research}

This research was conducted through a qualitative approach. Lexy (2015) explained that the characteristics of the qualitative researches consist of natural background as a data source or on the context of an intact object. Researchers themselves are the main instruments for collecting the data, inductive data analysis, descriptive research, strongly prioritizes the process than outcome, focusing on the limit, using basic theory, specific criteria for the validity of data, temporary design, and the research results are negotiated and agreed with altogether. The location of research was in Muhammadiyah elementary school of Dadapan, Turi, Sleman, DI Yogyakarta, Indonesia. Sugiyono (2016) described that research subjects are the people used to give information about the situation and condition in research location.

\subsection{Participants}

These research subjects were classroom teachers, students, special guidance teachers. Data is constantly dug up by researchers until the Data is saturated. To obtain saturated data, it did not limit to several people because, in qualitative research, the data will not dig up while the data has already saturated or have obtained Data triangulation.

\subsection{Data Collection and Analysis Techniques}

Data collection techniques based on Sugiyono (2016) are namely participant observation, in-depth interviews, and documentation. Participant observation is the technique of participating in obtaining data by observing and listening directly to what is done by the people, listening to what the people say, and participating in their activities (Satori \& Komariah, 2010). According to Susan Stainback in Sugiyono (2016) stated that interviewing provides the researcher with a means to gain a deeper understanding of how the participant interprets a situation or phenomenon that can be gained through observation alone. The researchers will learn more deeply about the participants in interpreting the situations and phenomena that occur through interviews, which cannot be found through the observation. 
Documentation is a complementing of using the observation and interview in qualitative research Sugiyono (2016). Documentation can be a documentation of the phenomena that had been passed in the form of archives, writings, drawings, or monumental works.

Data analysis techniques used by researchers on qualitative data obtained based on Huberman and Miles (1992) are data collection, data reduction, data display, conclusion withdrawal, and verification. 1) Data Collection. The data collected through the observation, interview, and documentation study. After collecting the data, it presented in the description of observation results, transcripts of the interviews, and documentation study. 2) Data reduction. Data reduction is the process of sorting data collected from the field. Data obtained from the interviews were grouped according to interview questions. After concluding the highlight of interview results, then these grouped by the observation results and documentation study-related. Furthermore, it takes the connection of the same pattern then compiled based on research questions. 3) Display Data. The Data was presented in narrative form according to research issue formulation. Exposure of research results accompanied by the evidence of the field from the interviews, observations, and documentation. From the research results, then researchers compare the results with the theory. 4) Conclusion withdrawal and verification. The result of data analysis is the conclusion and the suggestion on inclusive learning implementation.

\section{RESULTS}

The data presented in this research was based on the themes found by researchers on data collection and was also arranged to answer the proposed research questions.

\subsection{Inclusive Learning Plan}

Based on the interview with the classroom teacher of Muhammadiyah elementary school of Dadapan, Turi, Sleman, the inclusive learning plan described as follow:

"as usual, to implement the learning, we were guided by the 2013 curriculum. Before teaching, of course, we always make learning administrations such as syllabus, minimal mastery criteria, and learning implementation plan. The learning administrations become our reference in conducting classroom learning. However, the learning administrations we created still refers to learning administrations in general. We have not created yet special learning administrations for children with disabilities. We were still using the general learning program for them. The same learning implementation plan used for a class. However, the indicator referred to inclusive students".

The statement was enforced by special guidance teacher, as follow:

"in Muhammadiyah elementary school of Dadapan, in general, we have not yet created the specific learning administrations for children with disabilities, we, however, always modified the learning administrations by collaborating with classroom teachers and special guidance teacher in inclusive class to overcome the difficulties faced by the students in the class."

According to the abovementioned statements, those showed that the school arranged the learning administrations using guidelines on curriculum 2013. The learning administrations were syllabus, semester and annual program, and learning implementation plan.

The learning implementation plan was used together in a class, the indicators distinguished by adjusting to the ability of children with special needs. The learning plan in inclusive class was primarily the same as the learning plan in regular classes that were developing the syllabus and learning implementation plan used to implement the 
learning. The curriculum used is the regular curriculum modified as student needs related. The parties involved in making learning implementation plans are classroom teachers and special guidance teachers.

\subsection{Inclusive Learning Implementation}

The interview results with Muhammadiyah elementary school class teacher of Dadapan, Turi are:

"in implementing the learning, we were guided by learning plans that were arranged together with the special guidance teacher. We used a learning implementation plan for all of the students, both regular and special-needs students. The learning began by delivering learning purposes and motivations. The learning methods used were a lecture, discussion as well as questions and answers. The learning media were mediabased technology such as a liquid-crystal display (LCD) and laptop also other simple media. The media used for children with disabilities was the concrete and simple media customized to student's needs".

In line with the special guidance teacher:

"as a special guidance teacher, I used direct assistance and service as a learning method for special-needs children during the learning process in the class. Learning media utilization was adjusted by the learning media used by the classroom teacher. If the special-needs children experienced difficulties, I innovated to used more simple and concrete objects. The statement was enforced by the interview results of the regular student: before we began our class, usually teachers explained learning purposes, the students invited to sing together in order to be more excited. When the teachers taught, they delivered the subject materials using a lecture, discussion, as well as questions and answers. In the instruction, the teachers also used the learning media such as a liquid-crystal display (LCD) and a laptop. My friends and I liked to use that learning media because learning became more interesting”.

The observation results showed that in inclusive learning implementation in Muhammadiyah elementary school of Dadapan, Turi, the teachers began the class by delivering learning purposes continued by giving the motivation to the students such as inviting to sing together. The teachers used learning methods such as a lecture, discussion, questions, and answers. Special guidance teachers were seen to make direct assistance to children with special needs during the learning process. It looked likes that the teachers used liquid-crystal display (LCD) and a laptop in their learning. While the special guidance teachers conducted an adjustment and innovation to use more simple and concrete learning media to serve the children with special needs in the class.

According to the statements revealed by three informants and the results of the observation, those can be outlined that the teachers begin the learning by informing the learning purposes related to learning conducted by Muhammadiyah elementary school of Dadapan. The methods used in the learning process are lecture, discussion, questions, and answers. In which the special guidance teachers use the learning methods and accompanying the learning process in the class directly. Media used in learning is a media-based technology such as a liquid-crystal display (LCD) and laptop. For children with special needs, the media is more simple and concrete according to the ability of children with special needs.

\subsection{Inclusive Learning Evaluation}

To know the improvement of student learning outcomes, using the assessment becomes an integral part of learning implementation. The evaluation aims to know the development of student learning outcomes. The learning assessment conducted by Muhammadiyah elementary school of Dadapan, Turi is presented by the classroom teacher as follow: 
"when the teacher conducted the assessment, we certainly adjusted the assessment on curriculum 2013 used by our school. In the curriculum, there were four aspects of assessment; the assessment of attitude, spirituality, knowledge, and skills. All of the teachers in the school used the same assessment. We applied to all of the students, both regular students and children with special needs, so there is nothing we discerned".

It also conveyed by the special guidance teacher as follow:

"I, as a special guidance teacher, certainly followed the groove in this school. Because in this school used curriculum 2013, automatically, I also used the same aspects in curriculum 2013. There are four aspects of this assessment, namely, social attitude, spiritual attitude, knowledge, and skills. The assessment was to assess regular and inclusive student's aspects. Though the assessment standard was a difference, the learning adjusted by student's condition, especially for special-needs children”.

Except for conducting the interviews, the researcher also researched the documentation of the assessment in this school. The observation results of the learning evaluation documentation in Muhammadiyah elementary school of Dadapan showed that the assessment of learning outcomes included four aspects; social, spiritual, knowledge, and skills.

The abovementioned explanation described the implementation of the assessment in Muhammadiyah elementary school of Dadapan conducted by special guidance teachers through four aspects, according to curriculum 2013, as the current school curriculum. The four aspects are attitude, social, knowledge, and skills.

The assessment is used to provide an assessment of learning outcomes to all of the students in the school, whether it is for regular students and special needs students. The four aspects of the assessment also to assess the children with special needs, although the standards are distinguished with regular students and adapted to the conditions and the ability level of children with special needs.

It is further explained by the classroom teachers related to the following learning evaluations:

"to obtain the authentic results related to student's learning outcomes, we use several techniques to assess the aspects of attitudes through observation, self-assessment, peer-to-peer assessment, and teacher's record journals. For the knowledge assessment, it can be assessed by written tests, oral tests, and assignments. The skills assessment can be assessed using performance assessments, project assessments, and portfolio assessments. For children with special needs, we also make portfolio documents as consideration of the assessment. For portfolio documents, usually, some criteria are set relating to academic development, social development, and social maturity. Recently, this has always been conducted to monitor the progress of each child with special needs in this school".

Based on the above exposure, it is explained that the assessment has given an overview related to increased learning outcomes. An authentic assessment using observation techniques, self-assessment, peer-to-peer assessment, and teacher's record journals. The knowledge assessment uses written test techniques, oral tests, and assignments. Meanwhile, the skill assessment uses performance techniques, project assessments, and portfolios. For children with disabilities, the assessment uses academic criteria, social development, and social maturity.

In addition to conducting interviews, the researchers also conduct the observations related to the assessment techniques and observation results through the continued documentation, as follows:

"The results of the researchers showed that the assessment techniques conducted in Muhammadiyah Dadapan Elementary School in conducting teacher assessments use several techniques including assessment of the aspect of attitude conducted through observation technique, self-assessment, peer-to-peer assessment, and teacher's record journal. The knowledge assessment uses written tests, oral tests, and 
assignments. At the same time, the skills assessment aspect uses techniques of performance assessment, project assessments, and portfolio assessments."

As for the assessment of children with special needs, the teacher also made a portfolio document on the development of children with special needs in Muhammadiyah elementary school of Dadapan as consideration of the assessment. In addition, teachers also set criteria of grade promotion for children with special needs, i.e., academic criteria, social development criteria, and social maturity criteria.

Based on the results of interviews, observations and documentation, it can be concluded that in evaluating the learning of inclusion in the Muhammadiyah Elementary School of Dadapan, Turi, Sleman, DI Yogyakarta, uses curriculum 2013 standard with four assessment criteria namely attitude, social, knowledge, and skills. In conducting the assessment, attitude aspects use the techniques of observation, self-assessment, peer-to-peer assessment, and teacher's record journals. Meanwhile, the knowledge assessment uses written tests, oral tests, and assignments. The Skills assessment uses performance assessment techniques, projects, and portfolios. For children with special needs, the assessment uses three criteria, namely academic, social development, and social maturity.

\section{DISCUSSION}

This finding aims to discuss the implementation plan and evaluation of the inclusive learning in Muhammadiyah elementary school of Dadapan, Turi, Sleman, DI Yogyakarta. According to the data analysis, there are three important findings; first, an inclusive learning plan in Muhammadiyah elementary school of Dadapan is guided by curriculum 2013 modified according to the student's needs. That is, according to Yusuf (2014) stated that the special-needs students who have low intellectual ability need curriculum specifically modified, simple, and thematic to encourage students' independence in their daily life. Learning administrations such as learning implementation plan prepared by classroom teachers cooperated with special guidance teachers as well as a learning administration generally use in a class. In contrast, for children with special needs, the indicators used are adjusted by the student's ability. In line with Varvel (2007) study, he stated that teacher ability in developing the education, including program arrangement, program implementation conducted from planning to evaluating (assessing). The study relevance is needed three stages; learning plan, learning implementation, and learning evaluation followed by the feedback that is suitable for student's competency. Sukinah (2010) stated that inclusive education background emphasized the instilling of sympathy, respect, appreciation, and empathy toward the different social-culture backgrounds. The indicators of the learning implementation plan in Muhammadiyah elementary school of Dadapan, Turi, Sleman, DI Yogyakarta is adjusted by special-needs student's ability so that they can obtain the optimal learning service to improve special-needs student's independence and increase the emphaty toward the existence of the student with special-needs.

Secondly, the implementation of inclusive learning focuses on the use of learning methods and the use of learning media that can be described as follows: the methods usually used during the learning implementation in Muhammadiyah elementary school of Dadapan, Turi, Sleman, DI Yogyakarta is varied learning methods such as lecture, discussion, as well as questions and answers. This statement is according to the theory by the National Education Departement of 2009 that in inclusive education, the implementation of learning methods must be suitable with learning aims, and then the learning methods must be varied. In delivering learning materials, teachers need methods so that the learning implementation can be implemented well. If the methods do not implement well, the learning purposes will no be achieved. Siswoyo (2007) purposed that the learning methods are way or procedure to conduct teaching-learning activities in order to run well. Whereas Roestiyah (2001) said that teaching method is a presentation technique mastered by the teachers to teach or present the learning materials to 
the students in the class, moreover, what teachers taught can be accepted, understood (comprehensible), and used by students well. In the learning process, the teacher supposed to be smart and creative to use or choose suitable learning methods according to the subject material and student condition. The learning methods applied in Muhammadiyah elementary school of Dadapan, Turi, Sleman, DI Yogyakarta, are lecture, discussion, as well as questions and answers. The phases are appropriate with Sagala (Rusmiyati, 2008) that the methods used in learning implementation are lecture, tasks, questions and answers, discussion, and problem solving. In line with Sudjana (2005) he stated that there are learning methods such as lecture, discussion, as well as questions and answers.

Learning in inclusive school use a variety of methods, which one of them uses discussion as a learning method. This is appropriate with Shaw (2010) explained that one of the strategies to encourage slow-learner students are joined the student with their peers who can be a mentor for them (peer mentor). The teacher conducts this in using methods of learning through group discussions. Meanwhile, using the lecture method is in line with Triani and Amir (2013) stated that one of the strategies of the instructions is to help the special-needs students of a slow learner to use simple, clear, and slow language. To use the learning method, the teachers in Muhammadiyah elementary school of Dadapan, Turi, Sleman, DI Yogyakarta choose the learning method appropriate with the ability and characteristics of the students in the school. This is also in line with Surakhmad (1990) that the use of a suitable appropriate learning method will achieve the maximum learning results. In addition, it will bring the students to the directed learning process also means learning as well. The use of learning media in implementing the learning as tools to deliver the subject materials. Sudjana (2005) said that the use of learning media is an attempt to improve the interaction between students and teachers. Equivalently to Azwandi (2007) he stated that in choosing the learning media must understand student characteristic and difficulties.

The use of learning media for instruction in Muhammadiyah elementary school of Dadapan, Turi, Sleman, DI Yogyakarta, is media-based technology such as a liquid-crystal display (LCD) and laptop. Also, the use of learning media by laptop can help both the regular students and special-needs students to understand learning materials so that it is suitable for inclusive learning. In accordance with Shaw (2010) he said that the efforts that are pursued to strengthen the instruction are by using computer-assisted instruction. This also revealed by Triani and Amir (2013) that tools for children with disabilities, especially slow-learner children, are by using a learning program through computer or multimedia so that they can learn without pressure and depicted. Hamzah (2007) said that learning resources using pictures and videos combined with systematic media would support the learning program and impact student's performance.

Thirdly, the learning evaluation in Muhammadiyah elementary school of Dadapan is guided by curriculum 2013, the assessment measures through four criteria, namely social, spiritual, knowledge, and skills. The evaluation used by monitoring student learning activities and considering the aspects of the academic and non-academic assessment. The evaluation conducted through observation, portfolio, checklist form (skills, knowledge, and attitude), self-assessment, and the journal of reflection. The assessment of student results is a mandatory activity held by teachers to classify the level of student achievement, whether students are categorized completely or incompletely, also from the assessment, it is seen that either student will remediate or enrich the lessons.

The assessment of the inclusive learning evaluation is comprehensive and flexible. Comprehensiveness means spreading all over relating to the aspects of cognitive, affective, and psychomotor. While the flexibility means that the evaluation is adjusted to the situation and condition of students and their environment. The evaluation is adjusted by the competencies and indicators of learning outcomes that want to be achieved according to the material characteristics and evaluation objectives. The evaluation techniques are test and non-test. The test forms include oral tests and written tests. In which the non-test forms include observation, interviews, product valuation, 
performance, and portfolio. This is in line with Maftuhatin (2014) the evaluation conducted periodically, including daily exam, the Middle, and final semester assessment, both in an odd semester and even semester. From the evaluation, the teachers can take steps in the learning process, which the students who are difficult to read is done through delivery and remedial teaching program. The students who are difficult to write will remediate through remedial programs regarding difficulty level, as well as the student who is difficult to count is served by the systematic remedial program according to the sequence of concrete, semi-concrete, and abstract level. Primarily, the evaluation in the inclusive class aims to know the development of student outcomes. The learning evaluation is in an inclusive class held by various forms of evaluation, such as the daily exam, the Middle, and final Semester assessment. Inclusive learning evaluation is based on an appropriate evaluation instrument. This can increase the understanding of children with special needs toward what they learned, also give an overview of learning outcomes.

\section{CONCLUSION}

These findings concluded that 1) inclusive learning plan in Muhammadiyah elementary school of Dadapan is to make learning administrations guided by curriculum 2013. Syllabus and learning implementation plan used generally for special needs-children use the indicators according to their ability. 2) the learning implementation uses varied methods. The methods often used are lecture, discussion, as well as questions and answers. The teachers use the methods appropriate with the learning materials and student ability. The learning media used is media based on technology such as LCD and laptop. Media is simple concrete tools use to serve the special-needs children that need mentoring except using the method of laptop. 3) Learning evaluation conducted regarding curriculum 2013 by using four assessment criteria namely social, spiritual, knowledge, and skills. The evaluation conducted through two types of tests namely oral tests and written tests. The school conducts the learning evaluation in the middle and the end of the years, namely odd and even semester tests.

\section{ACKNOWLEDGMENT}

Our acknowledgment we deliver to a principal, teachers, special guidance teachers, and the students in Muhammadiyah elementary school of Dadapan and all of the lecturer of Universitas Ahmad Dahlan who support the researcher so that this research can be completed well.

\section{REFERENCES}

Amka, A. (2017). Implementation of inclusive character education for children with special needs in regular schools. Madrosatuna: Journal of Islamic Elementary School, 1(1), 1-12.

Ari, W. M. (2005). Implementation of learning at schools providing inclusive education at SDN Junrejo O1 Batu City. UM-Thesis.

Azwandi, Y. (2007). Learning media for children with special needs. Jakarta: Ministry of Education, Directorate General of Higher Education, Directorate of Manpower.

Dwiyanto, A. (2017). Public service management: Caring, inclusive, and collaborative. Yogyakarta: UGM Press.

Hamalik, O. (2008). Curriculum and learning. Jakarta: Bumi Aksara.

Hamzah, B. U. (2007). Motivation theory and its measurement analysis in the field of education. Jakarta: Earth Literacy.

Huberman, A. M., \& Miles, M. (1992). Qualitative data analysis. Jakarta: UII Press.

Illahi, T. (2013). Educational inclusion concepts and applications. Yogyakarta: AR Ruzz Media.

Indiyanto. (2013a). Implementation of inclusive education. Surakarta: FKIP UNS.

Indiyanto. (2013b). Implementation of inclusive education. Surakarta: FKIP UNS. 
Kim, Y.-W. (2014). Inclusive education in South Korea. International Journal of Inclusive Education, 18(10), 979-990. Available at: https://doi.org/10.1080/13603116.2012.693402.

Kustawan, D. (2012). Inclusive education \& its implementation efforts. Jakarta: Luxima.

Lexy, M. (2015). Qualitative research methods. Bandung: PT Remaja Rosdakarya.

Maftuhatin, L. (2014). Evaluation of learning for children with special needs (ABK) in inclusive classrooms at SD plus Darul'ulum Jombang. Religion: Journal of Islamic Studies, 5(2), 201-227.

Mangope, B., Mannathoko, M. C., \& Kuyini, A. B. (2013). Pre-service physical education teachers and inclusive education: Attitudes, concerns and perceived skill needs. International Journal of Special Education, 28(3), 82-92.

Menteri Pendidikan Nasional. (2009). Regulation of the Minister of National Education of the Republic of Indonesia Number 70 of 2009 concerning Inclusive Education for Students with Disabilities and Potential Intelligence and / or Special Talents.

Murtie, A. (2016). Encyclopedia of children with special needs. Yogyakarta: Editor of Maxima.

Nana, S. (1989). Assessment of teaching and learning process outcomes. Bandung: PT Remaja Rosdakarya.

Prastiyono. (2013). Implementation of inclusive education policies. Journal of Public Administration, 11(1), 117 -128.

Roestiyah. (2001). Teaching and learning strategies. Jakarta: PT Rineka Cipta.

Rusmiyati. (2008). Citizenship education development in elementary schools. Jakarta: Depdiknas.

Satori, D. a., \& Komariah, A. (2010). Qualitative research methodology. Bandung: Alfabeta.

Shaw, S. R. (2010). Rescuing students from the slow learner trap. Principal leadership (pp. 12-16). Canada: National Associations of Secondary School Principal.

Siswoyo, D. (2007). Science education. Yogyakarta: UNY Press.

Smith, J. D. (2006). Inclusion of friendly schools for all (Muhammad Suarmin translation). Bandung: Publisher Nuansa.

Stainback, S. W. (1990). Support network for inclusive schooling. Baltimore: Independent Integrated/Education., Paul H Brooker.

Sudjana, N. (2005). Statistical method (Vol. 168). Bandung: Tarsito.

Sugiyono. (2016). Combination research methods. Bandung: Alfabeta.

Sukinah. (2010). Strategic management of inclusive education implementation. Journal of Special Education, 7(2), 40-51.

Surakhmad. (1990). Introduction to scientific research: Basics, methods, and techniques. Bandung: Tarsito.

Tarmansyah. (2007). Inclusion: Education for all. Jakarta: Depdiknas Director General of Higher Education.

Tarnoto, N. (2016). The problems faced by schools that provide inclusive education at the elementary level. Humanity: Journal of Psychology, 13(1), 50-61.

Triani, N., \& Amir. (2013). Education of children with special needs is slow to learn (Slow Learner). Jakarta: Luxima.

Varvel, E. V. (2007). Master online teacher competencies. Online Journal of Distance Learning Administration, $10(1), \mathrm{n} 1$.

Yusuf, M. (2014). Management model for inclusive education in primary schools. Semarang: Semarang State University.

Online Science Publishing is not responsible or answerable for any loss, damage or liability, etc. caused in relation to/arising out of the use of the content. Any queries should be directed to the corresponding author of the article. 